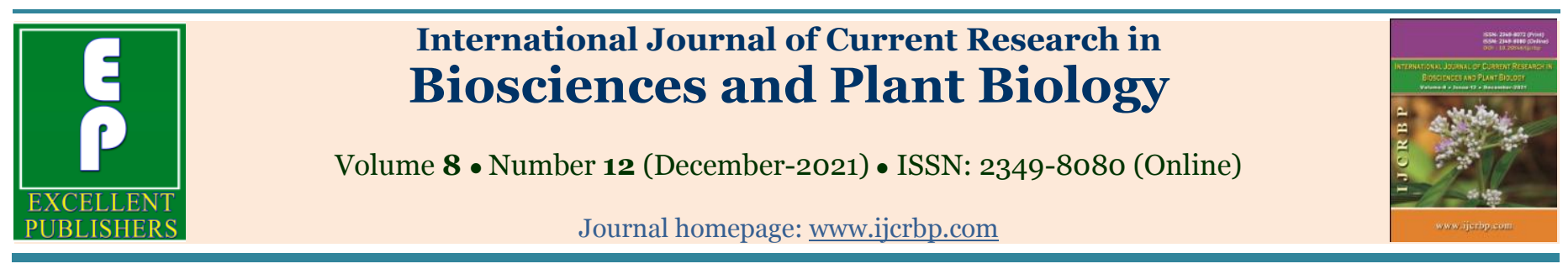

Original Research Article

doi: https://doi.org/10.20546/ijcrbp.2021.812.002

\title{
Application of biocompost enriched with arbuscular mycorrhizae for the growth of Allium cepa $\mathrm{L}$.
}

\section{Muh. Akhsan Akib ${ }^{1}{ }^{1}$, Sarjiya Antonius $\mathbb{D}^{2}$, Tutik Kuswinanti ${ }^{3}$, Syatrawati $^{4}$, Tirta Kumala Dewi ${ }^{2}{ }^{2}$, Entis Sutisna ${ }^{2}{ }^{2}$}

\author{
${ }^{1}$ Universitas Muhammadiyah Parepare. South Sulawesi, 91131, Indonesia \\ ${ }^{2}$ Indonesian Institute of Science, Jakarta, 12710, Indonesia \\ ${ }^{3}$ Hasanuddin University, South Sulawesi, 90245, Indonesia \\ ${ }^{4}$ Pangkep State Polytechnic of Agriculture, South Sulawesi, 90761, Indonesia
}

*Corresponding author; e-mail: akhsanbagus@yahoo.co.id

\begin{tabular}{|c|c|}
\hline Article Info & Abstract \\
\hline $\begin{array}{l}\text { Keywords: } \\
\text { Biological agents } \\
\text { Compost } \\
\text { Mycorrhizae } \\
\text { Onion } \\
\text { Organic fertilizer }\end{array}$ & 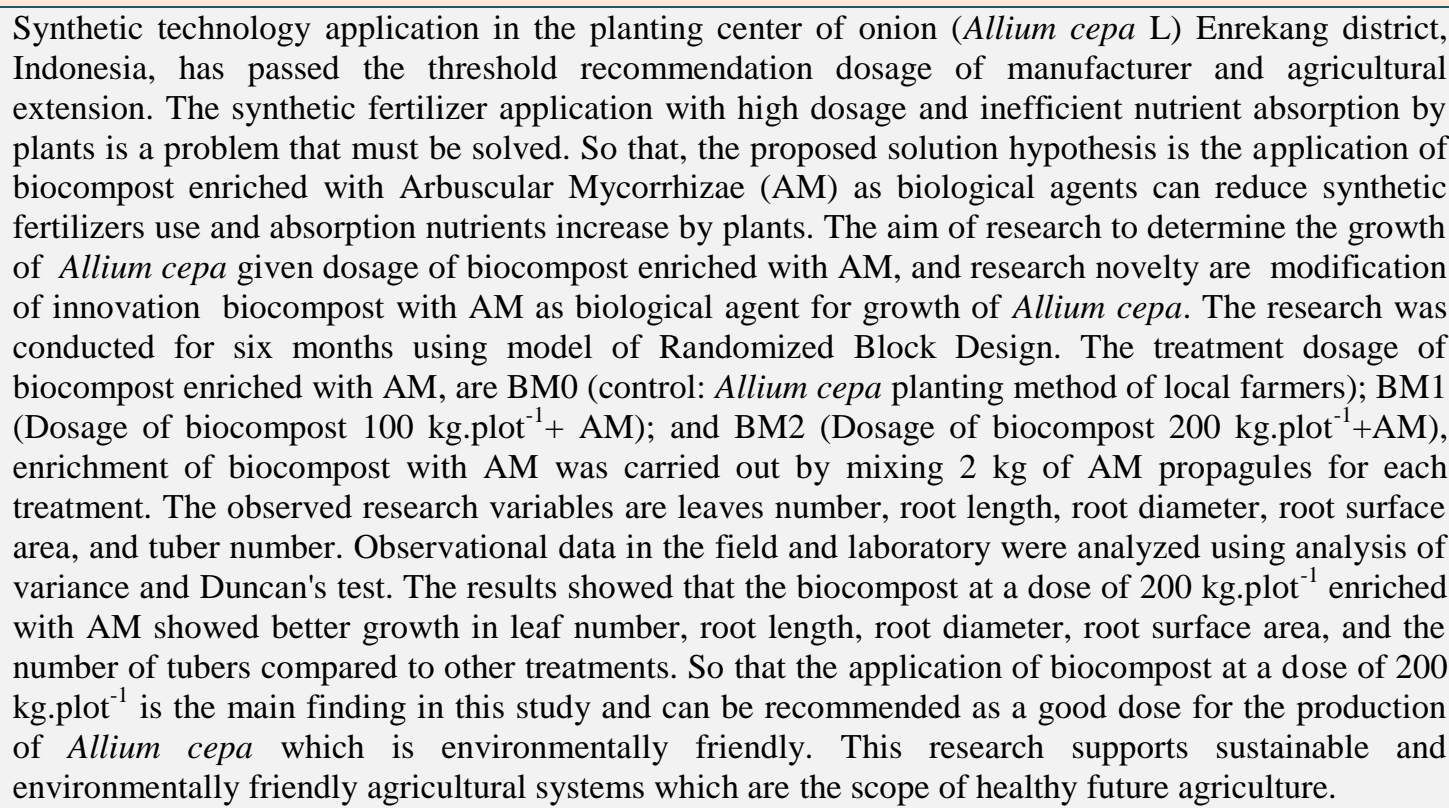 \\
\hline
\end{tabular}

- Received: 3 October 2021 • Revised: 1 November 2021 • Accepted: 26 November 2021 • Published Online: 6 December 2021 


\section{Introduction}

Onion (Allium cepa L.) is one of the main commodities of horticultural crops that have long been intensively cultivated by community in Enrekang regency, Indonesia. This vegetable commodity belongs to the group of spices that function as food seasoning (Bamba et al., 2020; Marta et al., 2020) and traditional medicine (Chernukha et al., 2021; Marefati et al., 2021), which have high economic value.

Synthetic technology innovations in Allium cepa planting centers have been widely applied by farmers, but are still oriented towards increasing the quantity of production and not yet oriented towards improving the quality of production. (Asaad, 2014) explained that the use of organic fertilizer by Allium cepa farmers in Enrekang has been applied but still uses chemical fertilizers at a dose of $250 \mathrm{~kg}$ urea $+50 \mathrm{~kg} \mathrm{ZA}+50 \mathrm{~kg}$ SP-36 + $50 \mathrm{~kg}$ Ponska, and exceeded the recommended dose by agricultural extension. This allows for excessive use of nutrients so that they can become a source of pollution for water, soil, and the Allium cepa product.

Arbuscular mycorrhizae (AM) use as biological agents to reduce chemical fertilizers use (El-Sherbeny et al, 2022; Trejo et al., 2021), increase of water use efficient (Begum et al., 2019; El-Tohamy et al., 2021), and increase nutrient absorption (Begum et al., 2019; Li et al., 2020) has been researched and applied to various horticultural crops (Golubkina et al., 2020; Karti et al., 2021), food crops (Campo et al., 2020; Addo et al., 2020), plantation crops (Fajariza et al., 2020; PenaVenegas et al, 2021; Rini et al., 2021), fodder forage crops (Rosita et al., 2020; Karti et al., 2021) and afforestation crops (Aji et al., 2021; Husna et al., 2021). However, the use of biocompost fertilizer has not been widely applied by Allium cepa farmers by utilizing microorganisms as biological agents to absorption maximized of nutrients contained in the bio compost. So that need a research on the innovation of biocompost which enriched AM as Allium cepa growth stimulation.

The aim of research is to determine the Allium cepa growth given a dosage of biocompost enriched with $\mathrm{AM}$, while research novelty is modification of bio compost innovation with AM as biological agent for Allium cepa growth stimulation.

\section{Materials and methods}

The research was carried out on area Allium cepa plantation in Sipate village, Anggeraja sub-district, Enrekang, Indonesia at an altitude of 1022 m.a.s.l which uses full synthetic chemical technology. The soil chemical properties on the land used for planting Allium cepa can be seen in Table 1.

Table 1. Soil chemical properties on area onion plantation in Sipate, Anggeraja sub-district, Enrekang in the district. Indonesia, and the quality of goat feces biocompost.

\begin{tabular}{llllllllll}
\hline Items & $\mathbf{p H}$ & $\mathbf{C E C}$ & $\mathbf{B S}(\boldsymbol{\%})$ & $\mathbf{C} / \mathbf{N}$ & $\mathbf{N}(\boldsymbol{\%})$ & $\mathbf{P}_{\mathbf{2}} \mathbf{O}_{\mathbf{5}}$ & $\mathbf{K}$ & $\mathbf{M g}$ & $\mathbf{N a}$ \\
\hline Area onion plantation & 6.72 & 20.00 & 41 & 6 & 0.17 & 12.94 & 0.17 & 1.07 & 0.24 \\
Biocompost of goat feces & 6.55 & - & - & 19 & 1.26 & 0.93 & 0.45 & & \\
\hline
\end{tabular}

The research were arranged using a randomized block design and treatment dosage of biocompost enriched with AM used were BM0 (control: local farmer's method of planting Allium cepa); BM1 (Dose of biocompost $100 \mathrm{~kg} \cdot \mathrm{plot}^{-1}+\mathrm{AM}$ ), and BM2 (Dose of biocompost, $\left.200 \mathrm{~kg} \cdot \mathrm{plot}^{-1}+\mathrm{AM}\right)$. Each treatment repeated in 3 plots with area of $15 \mathrm{~m} \times 15 \mathrm{~m}$ per plot. Enrichment of biocompost with AM was carried out by mixing $2 \mathrm{~kg}$ of AM propagules for each treatment.

The biocompost used is delivered from the fermentation of goat feces, which is a business owned by the people of Enrekang district (the biocompost quality can be seen in Table 1), while AM used to enrich biocompost were isolated from various of crop rhizospheres in areas that have been contaminated with heavy metals of $\mathrm{Ni}, \mathrm{Fe}, \mathrm{Pb}$ $\mathrm{Cr}, \mathrm{Cu}$, dan Co. Morphological identification of AM spores, multiplication of spores using culture media and host plants have been carried out in the early stages of research.

Components of observing the effectiveness of biocompost enriched with AM included plant height, leaves number, root length, root diameter, root surface area, and tuber of Allium cepa number, which were carried out in the mini-laboratory of Agroplastid Farm, Parepare; while the analysis of soil characteristics was carried out at the soil chemistry and fertility laboratory 
of Hasanuddin University, Makassar. Data from observations in the field and in the laboratory were analyzed using analysis of variance and Duncan's test.

\section{Results and discussion}

\section{Number of leaves}

Analysis of variance showed that the treatment of biocompost enriched with AM does significant effect on leaves number of Allium cepa, and the results of Duncan's test showed that Allium cepa with treated biocompost of $200 \mathrm{~kg} \cdot$ plot $^{-1}$ enriched with AM had a higher number of leaves and significantly different from other treatments (Fig. 1). This phenomenon is probably caused by the addition of $\mathrm{C} / \mathrm{N}$ contained in biocompost enriched with AM can improve the physical, chemical, and biological properties of the soil, moreover, the addition of biological agents of AM can help the absorption of water and nutrients for plant growth.

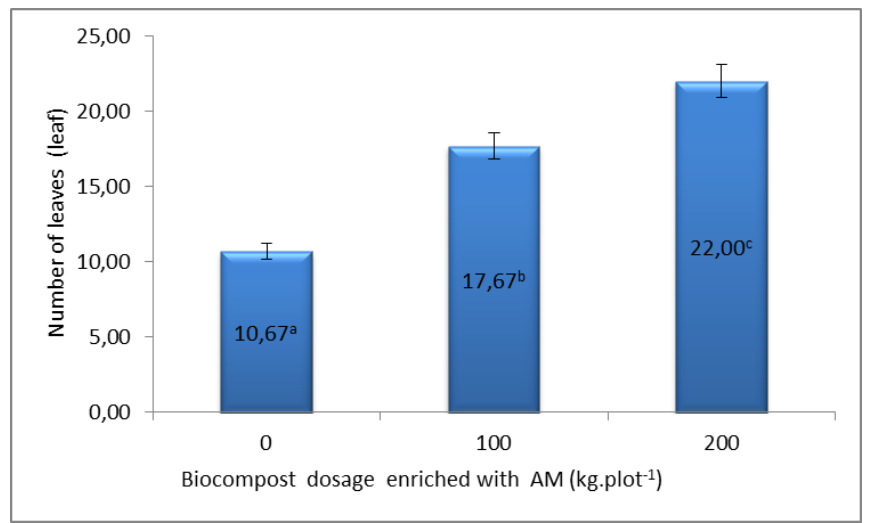

Fig. 1: Average of Allium cepa leaves number given biocompost enriched AM.

The high-value $\mathrm{C} / \mathrm{N}$ ratio indicates that organic matter still needs process advanced of decomposition so that nitrogen $(\mathrm{N})$ can be available and occur balance nutrient concentrations in the soil according to plant needs which ultimately stimulates Allium cepa to form new leaves.

Organic fertilizers can provide good growing environment for plants (Shang et al., 2020; Anggraini et al., 2021), so organic fertilizers must be applied in large quantities to provide macro- and micro-nutrients needed for optimal plant growth and performance (Adekiya et al., 2020; Kumar et al., 2021). However, organic fertilizer obtained from goat manure generally has a $\mathrm{C} / \mathrm{N}$ value greater than 30 , so it must be decomposed first, as good manure must have a $\mathrm{C} / \mathrm{N}$ value less than
20 (Trivana and Pradhana, 2017; Batubara et al., 2021).

\section{Root length}

Variance test showed that the Allium cepa root length variable was significantly affected by biocompost enriched with AM. Whereas, Duncan's test showed that the application of 100 and $200 \mathrm{~kg} \cdot$ plot $^{-1}$ biocompost enriched with AM gave root length not different effect significantly (Fig. 2). This phenomenon is possibly caused by the provision of biocompost enriched with AM can contribute K elements for the growing roots of Allium cepa (Table 1), so that roots grow more actively to nutrients absorb contained in biocompost which present at layer soil on the depth of 5 to $15 \mathrm{~cm}$. Besides that symbiosis of roots and AM is also very supportive of the absorption of water and nutrients through external hyphae.

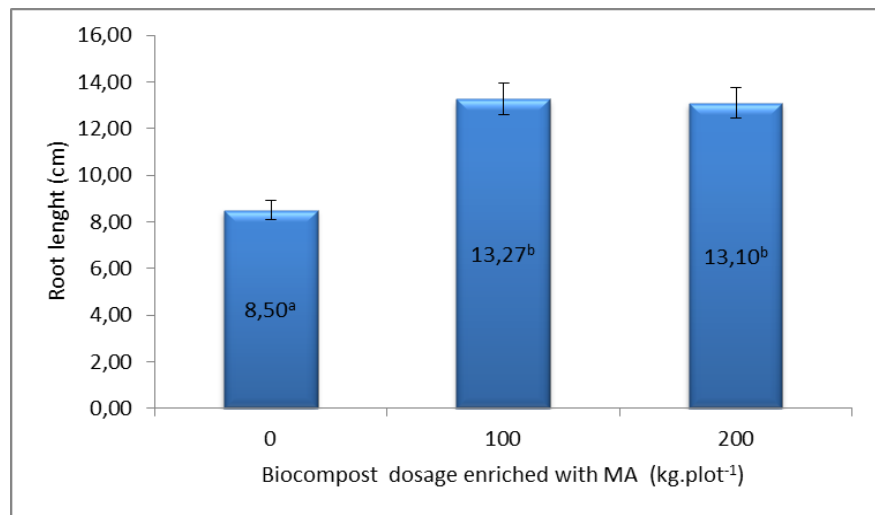

Fig. 2: Average of Allium cepa root length given biocompost which enriched AM.

According to Sustr et al. (2019) and Kumar et al. (2021) that one of the potassium element functions is to stimulate root meristem cell division so that grows lengthwise to absorb water and nutrients. The results of Song et al. (2015) and Sustr et al. (2019) showed that potassium deficiency could inhibit lateral root length, lateral root number, and total root length in cotton sprouts.

Potassium is a macronutrient that has roles in regulating plant physiological processes such as cell division, photosynthesis, opening and closing of stomata, regulating water distribution in tissues and cells, transporting nutrients from roots to leaves, accumulation and translocation of sucrose, filling seeds and tubers, root growth, cellulose synthesis, strengthen cell walls and stems, play a role in enzymatic systems, plant resistance, protein synthesis, $\mathrm{pH}$ regulation, affect 
the quality (taste, color, and weight) of fruit and flowers, increase plant resistance to drought, pests/diseases, accelerate the growth of meristem tissue (Hasanuzzaman et al., 2018; Xu et al., 2020; Sardans and Penuelas, 2021).

\section{Root diameter}

Results of variance analysis showed that the treatment of biocompost enriched with AM had a significant effect on root diameter variables of Allium cepa. Furthermore, Duncan's test showed that the highest mean value of root diameter obtained on the application of $200 \mathrm{~kg} \cdot$ plot $^{-1}$ biocompost enriched with AM and was significantly different from other treatments (Fig. 3). This phenomenon is probably caused by the addition of nitrogen $(\mathrm{N})$ and phosphate $(\mathrm{P})$ elements derived from biocompost enriched with AM (Table 1) which can increase the assimilating production in leaves through the photosynthesis process and accumulate to plant lower organs for root growth including root diameter so that expanding absorption area. Besides that, the absorption of water and nutrients is also carried out by external hyphae of AM.

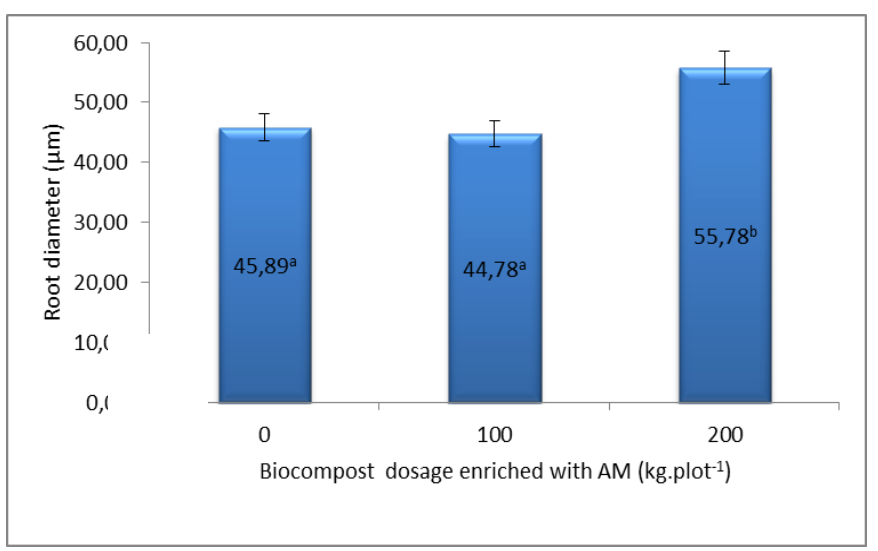

Fig. 3: Average of Allium cepa root diameter given biocompost which enriched AM.

According to Shrestha et al. (2020) and Savarino et al. (2021), $\mathrm{N}$ as macronutrient function to stimulate plant growth, assimilate produced through the photosynthesis process are a source of energy for plants to carry out further metabolic processes (Walker et al., 2020; Stephens et al., 2021), which also a source of energy for $\mathrm{AM}$ as a form of mutualistic symbiosis between plants and mycorrhizae (Sugiura et al., 2020; Yu et al., 2020). Besides that, the photosynthesis product in the form of assimilate constitute the source of energy used for three activities, namely: (1) for plant growth (Ajdanian et al.,
2020; Yavari et al., 2021), (2) stored as food reserves (Siahpoosh, 2014; Aluko et al., 2021), and (3) stored as a sink which is a form of plant economic yield (Arifin et al., 2019; Sales et al., 2021).

Phosphate (P) is the second essential element after $\mathrm{N}$ which plays an important role in photosynthesis and stimulates root development. Roots that are not well developed cannot absorb more nutrients (Szulc et al., 2020; Vysotskaya et al., 2020; Etesami et al., 2021).

\section{Root surface area}

Analysis of variance showed that treatment of biocompost enriched with AM had a significant effect on the root surface area of Allium cepa, and then Duncan test results showed that shallots treated with $200 \mathrm{~kg} \cdot \mathrm{plot}^{-1}$ biocompost enriched with AM, had a wider root surface area than other treatments (Fig. 4). This phenomenon was closely related to the variables of root length and root diameter. Plants that have a high value of root length and diameter will have a wide root surface area.

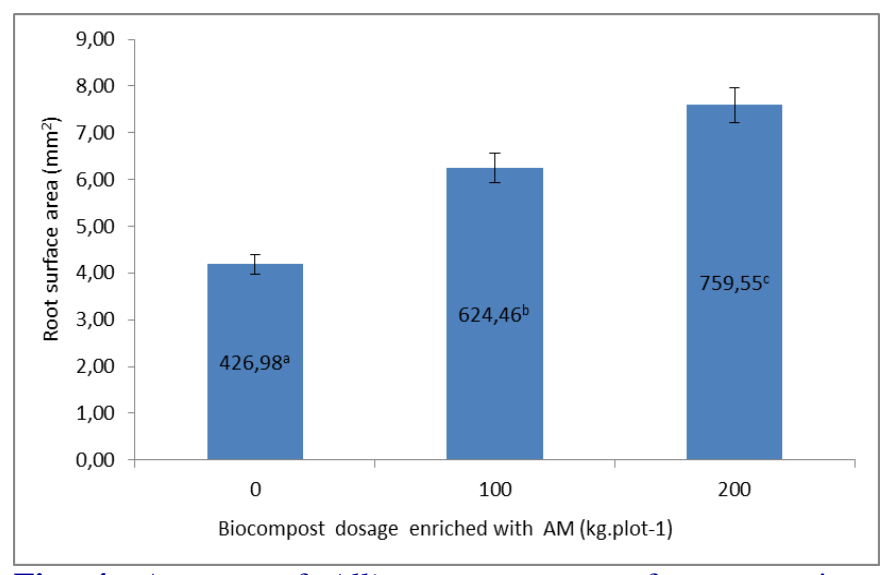

Fig. 4: Average of Allium cepa root surface area given biocompost which enriched AM.

The wide root surface will cause the absorption of water and nutrients to be very effective because the contact between the surface of soil particles and root surface is wider, besides that surface contact also occurs between the external hyphae of AM with the surface of soil particles so as to further increase the absorption of water and nutrients to meet plant needs. According to (Huang et al., 2020; Etesami et al., 2021). that one of the roles of arbuscular mycorrhizae is to increase the root's specific surface area so that can reach nutrients in the soil. 


\section{Number of bulbs}

Results of variance analysis showed that treatment of biocompost enriched with AM had significant effect on number of tubers Allium cepa. The dose of biocompost $200 \mathrm{~kg} \cdot \mathrm{plot}^{-1}$ enriched with superior AM gave a different effect with the dose of biocompost $100 \mathrm{~kg}$.plot ${ }^{-}$ 1 enriched with superior AM and without giving biocompost enriched with AM (Fig. 5). This phenomenon can be suspected that additional nutrients $\mathrm{N}, \mathrm{P}$, and $\mathrm{K}$ from biocompost caused plants to experience better growth and increase the tuber number of Allium cepa, which also cannot be separated from the war of AM as an agent biological in absorption water and nutrients.

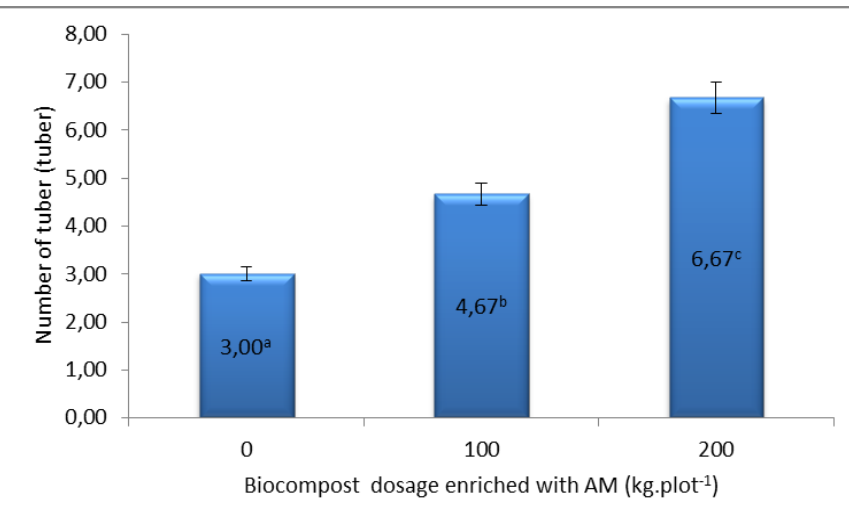

Fig. 5: Average number of Allium cepa tuber in biocompost enriched with AM.

Allium cepa require input of nutrients are used as a source of energy for the growth process. Nutrients nitrogen, phosphate, and potassium are important factors and must always be available to plants, because they function in the metabolic and biochemical processes of plant cells (Feng et al., 2020; Paiman et al., 2021; Wang et al., 2021). Nitrogen as a builder of nucleic acids, proteins, bioenzymes, and chlorophyll (Raul et al., 2016; Feng et al., 2020; Kishorekumar et al., 2020). Phosphorus as a builder of nucleic acids, phospholipids, bioenzymes, proteins, metabolic compounds, and is an important part of ATP in energy transfer (Stigter and Plaxton, 2015; Kolodiazhnyi, 2021). Potassium regulates the balance of ions in cells, which functions in regulating various metabolic mechanisms such as photosynthesis, carbohydrate metabolism and translocation, protein synthesis plays a role in the respiration process and increases plant resistance to pests and diseases (Hasanuzzaman et al., 2018; Dar et al., 2021; Torabian et al., 2021).

Mutualism symbiosis between MA and the root system of Allium cepa, both provide mutual benefits. Mycorrhizae work by infecting the root system of Allium cepa in producing an external hyphae network that grows expansively and penetrates the sub-soil layer of the soil, thereby increasing the root's capacity to absorb nutrients and water. Manan et al. (2021) and Rubin and Gorres (2021) explained that the extensive mycelium system (vegetative part of the fungus) effectively scoured the soil substrate to obtain soil inorganic nutrients including macronutrients $\mathrm{N}, \mathrm{P}$ and $\mathrm{K}$ and several micronutrients, $\mathrm{Cu}, \mathrm{Fe}$ and $\mathrm{Zn}$ (Begum et al., 2019; Xue and Wang, 2020; Liu et al., 2021), with some of capacity to obtain organic nitrogen and phosphorus (Li et al., 2019; Lin et al., 2020). The nutrients obtained are not only important for the development of the mycorrhizae themselves but are also partially transferred to the host plant (Begum et al., 2019; Sagar et al., 2021).

\section{Conclusions}

The growth and production of Allium cepa by giving biocompost $200 \mathrm{~kg}$.plot ${ }^{-1}$ enriched with AM resulted in better growth of leaf number, root length, root diameter, root surface area and number of tubers compared to other treatments. This dose can be a solution to reduce the use of synthetic fertilizers, increase the efficiency of nutrient absorption, and filter the absorption of heavy metals so that system of healthy agricultural, sustainable, and environmentally friendly can be realized to maintain human health and save our earth.

\section{Conflict of interest statement}

Authors declare that they have no conflict of interest.

\section{Acknowledgement}

Our research team would like to thanks The National Research and Innovation Agency (Indonesian: Badan Riset dan Inovasi Nasional, BRIN) and The Ministry of Education, Culture, Research, and Technology (Indonesian: Kementerian Pendidikan, Kebudayaan, Riset, dan Teknologi, KEMDIKBUDRISTEK) on support provided through funding The National Research Priority, so that this research can be carried out in 2021. 


\section{References}

Adekiya, A. O., Ejue, W. S., Olayanju, A., Dunsin, O., Aboyeji, C. M., Aremu, C., Adegbite, K., Akinpelu, O., 2020. Different organic manure sources and NPK fertilizer on soil chemical properties, growth, yield and quality of okra. Sci. Rep., 10(1): 1-9.

Addo, E. S., Yasuda, M., Lee, C. G., Kanasugi, M., Fujii, Y., Omari, R. A., Abebrese, S. O., Bam, R., Brempong, S. A., Dastogeer, K. M. G., Okazaki, S., 2020. Arbuscular Mycorrhizal Fungi Associated with Rice (Oryza sativa L.) in Ghana: Effect of regional locations and soil factors on diversity and community assembly. Agronomy, 2020(10): 559.

Ajdanian, L., Babaei, M., Aroiee, H., 2020. Investigation of photosynthetic effects, carbohydrate and starch content in cress (Lepidium sativum) under the influence of blue and red spectrum. Heliyon, 6(12): e05628.

Aji, O. R., Utami, I., Cahyanti, C., 2021. Abundance of associated arbuscular mycorrhizal fungi with pioneer plants in affected area by Mount Merapi eruption. J. Manajemen Hutan Trop., 27(1):100109.

Aluko, O. O., Li, C., Wang, Q., Liu, H., 2021. Sucrose utilization for improved crop yields: A review article. Int. J. Mol. Sci., 22(9): 1-29.

Anggraini, W., Fiteriani, I., Prihantini, N. N., Rahmawati, F., Susanti, A., Septiyani, E., 2021. The effect of organic fertilizers and inorganic fertilizer on mustard growth in Bahway village, Balik Bukit district, West Lampung regency. IOP Conf. Ser.: Earth and Environmental Science, 1796(1): 012004.

Arifin, B., Achsani, N. A., Martianto, D., Sari, L. K., Firdaus, A. H., 2019. The future of Indonesian food consumption. J. Ekonomi Indonesia, 8(1): 71-102.

Asaad, M., Warda, 2014. Kajian Penggunaan Pupuk Organik Pada Tanaman Bawang Merah Asal Biji Di Kabupaten Sidrap, Sulawesi Selatan. J. Pengkajian Pengembangan Teknologi Pertanian, 13(1): 20-28.

Bamba, B. S. B., Komenan, A. C. A., Kouassi, K. K. P., Soro, D., 2020. Effects of onion bulb processing conditions on drying characteristics, physicochemical and functional properties profile of onion (Allium cepa L.) powder. J. Food Sci., 85(10): 3345-3354.

Batubara, S. F., Santoso, A. B., El Ramija, K., 2021. Potential of goat manure as organic fertilizer in North Sumatera. BIO Web of Conferences, 33: 05001.

Begum, N., Qin, C., Ahanger, M. A,, Raza, S., Khan,
M. I., Ashraf, M., Ahmed, N., Zhang, L. 2019. Role of arbuscular mycorrhizal fungi in plant growth regulation: Implications in abiotic stress tolerance. Front. Plant Sci., 10: 1068.

Campo, S., Martín-Cardoso, H., Olive, M., Pla, E., Catala-Forner, M., Martínez-Eixarch, M., Segundo, B. S., 2020. Effect of root colonization by arbuscular mycorrhizal fungi on growth, productivity and blast resistance in rice. Rice, 13(42):1-14.

Chernukha, I., Fedulova, L., Vasilevskaya, E., Kulikovskii, A., Kupaeva, N., Kotenkova, E., 2021. Antioxidant effect of ethanolic onion (Allium cepa) husk extract in ageing rats. Saudi J. Biol. Sci., 28(5): 2877-2885.

Dar, J. S., Cheema, M. A., Rehmani, M. I. A., Khuhro, S., Rajput, S., Virk, A. L., Hussain, S., Bashir, M. A., Alghanem, S. M., Al-Zuaibr, F. M., Ansari, M. J., Hessini, K., 2021. Potassium fertilization improves growth, yield and seed quality of sunflower (Helianthus annuus L.) under drought stress at different growth stages. PLoS One, 16(9): e0256075.

El-Sherbeny, T. M. S., Mousa, A. M., El-Sayed, E. S. R. 2022. Use of mycorrhizal fungi and phosphorus fertilization to improve the yield of onion (Allium cepa L.) plant. Saudi J. Biol. Sci., 29, 331-338.

El-Tohamy, W. A., Bard, M. A., Abou-Hussein, S. D., 2021. Impact of arbuscular mycorrhiza on uptake, growth, yield and water relations of vegetable plants subjected to drought stress : A review. Int. J. Environ., 10(2): 83-87.

Etesami, H., Jeong, B. R., Glick, B. R., 2021. Contribution of arbuscular mycorrhizal fungi, phosphate-solubilizing bacteria, and silicon to $\mathrm{P}$ uptake by plant. Front. Plant Sci., 12: 699618.

Feng, H., Fan, X., Miller, A. J., Xu, G., 2020. Plant nitrogen uptake and assimilation: Regulation of cellular pH homeostasis. J. Exp. Bot., 71(15): 43804392.

Fajariza, D. F., Muhibuddin, A., Sektiono, A. W., 2020. Pengaruh Mikoriza Terhadap Penyakit Layu Fusarium (Fusarium oxysporum) pada tembakau (Nicotiana tabacum L.) Dalam media pasir kuarsa mengandung kompos amb-p0k. J. Tanah Sumberdaya Lahan, 7(1): 31-38.

Golubkina, N., Krivenkov, L., Sekara, A., Vasileva, V., Tallarita, A., Caruso, G., 2020. Prospects of arbuscular mycorrhizal fungi utilization in production of Allium plants. Plants, 9(2): 1-16.

Hasanuzzaman, M., Bhuyan., M. H. M. B., Nahar, K., 
Hossain, M. S., Mahmud J. A., Hossen, M. S., Masud, A. A. C., Moumita, Fujita, M., 2018. Potassium: A vital regulator of plant responses and tolerance to abiotic stresses. Agronomy, 8(3): 1-29.

Huang, G. M., Zou, Y. Y., Wu, Q. S., Xu, Y. J., Kuca, K., 2020. Mycorrhizal roles in plant growth, gas exchange, root morphology, and nutrient uptake of walnuts. Plant, Soil Environ., 66(6): 295-302.

Husna, Tuheteru, F. D., Arif, A., 2021. Arbuscular mycorrhizal fungi to enhance the growth of tropical endangered species pterocarpus indicus and pericopsis mooniana in post gold mine field in southeast Sulawesi, Indonesia. Biodiversitas, 22(9): 3844-3853.

Karti, P. D. M. H., Prihantoro, I., Aryanto, A. T., 2021. Evaluation of inoculum arbuscular mycorrhizal fungi in Brachiaria decumbens. IOP Conf. Ser.: Earth and Environmental Science, 694: 012048.

Kishorekumar, R., Bulle, M., Wany, A., Gupta, K. J., 2020. An overview of important enzymes involved in nitrogen assimilation of plants. Methods Mol. Biol. 2057: 1-13.

Kolodiazhnyi, O. I., 2021. Phosphorus compounds of natural origin: Prebiotic, stereochemistry, application. Symmetry, 13(889): 2-52.

Kumar, S., Kumar, S., Mohapatra, T., 2021. Interaction between macro- and micro-nutrients in plants. Front. Plant Sci., 12: 665583.

Li, Z. Ngwene, B., Hong, T., George, E., 2019. Effects of nitrogen feeding for extraradical mycelium of Rhizophagus irregularis maize symbiosis incorporated with phosphorus availability. J. Plant Nutr. Soil Sci., 182(4): 647-655.

Li, Z. Wu, N., Meng, S., Wu, F., Liu, T., 2020. Arbuscular mycorrhizal fungi (AMF) enhance the tolerance of Euonymus maackii Rupr. at a moderate level of salinity. PLoS One, 15(4): 1-16.

Lin, C. Wang, Y., Liu, M., Li, Q., Xiao, W., Song, X., 2020. Effects of nitrogen deposition and phosphorus addition on arbuscular mycorrhizal fungi of Chinese fir (Cunninghamia lanceolata). Sci. Rep., 10(1): 18.

Liu, R. C., Xiao, Z. Y., Hashem, A., Allah, E. F. A., $\mathrm{Xu}$, Y. J., $\mathrm{Wu}$, Q. S., 2021. Unraveling the interaction between arbuscular mycorrhizal fungi and camellia plants. Horticulturae, 7(322): 1-12.

Manan, S., Ullah, M. W., Islam, M. U., Atta, O. M., Yang, G., 2021. Synthesis and applications of fungal mycelium-based advanced functional materials. J. Bioresour. Bioprod., 6(2021): 1-10.

Marefati, N., Ghorani, V., Shakeri, F., Boskabady, M.,
Kianian, F., Rezae, R., Boskabady, M. H., 2021. A review of anti-inflammatory, antioxidant, and immunomodulatory effects of Allium cepa and its main constituents. Pharmaceut. Biol., 59(1): 287302.

Marta, N., Kuswandi., Andini, M., Sunyoto., Irawati, Y., Nofiarli., Nasution, F., 2020. The effect of the medium and the variety on the yield of shallots (Allium ascalonicum L.) grown in a polybag. J. Trop. Hort., 3(1):19-22.

Paiman., Ardiyanta., Kusumastuti, C. T., Gunawan, S., Ardiani, F., 2021. Maximizing the rice yield (Oryza Sativa L.) using NPK fertilizer. Open Agric. J., 15(1): 33-38.

Pena-Venegas, C. P., Sterling, A., Andrade-Ramírez, T. K., 2021. Arbuscular mycorrhization in colombian and introduced rubber (Hevea brasiliensis) genotypes cultivated on degraded soils of the Amazon Region. Agriculture (Switzerland), 11(361): 1-17.

Raul, R. G., Irineo, T. P., Gerardo, G. G. R., Miguel, C. M. L., 2016. Biosensors used for quantification of nitrates in plants. J. Sensors, 2016: 1-12.

Rini, M. V., Suharjo, R., Wibowo, L., Irvanto, D., Ariyanto, A., 2021. Seleksi empat jenis fungi mikoriza arbuskular pada bibit kelapa sawit yang ditanam pada tanah histosol. Menara Perkebunan, 89(1): 8-16.

Rosita, R., Widyastuti, R., Mansur, I., Faulina, S. S., 2020. Potential use of Claroideoglomus etunicatum to enrich signal grass (Brachiaria decumbens Stapf.) for silvopasture preparation. E-J. Menara Perkebunan, 88(1): 61-68.

Rubin, J. A., Gorres, J. H. 2021. Potential for mycorrhizae-assisted phytoremediation of phosphorus for improved water quality. Int. J. Environ. Res. Public Health, 18(7): 1-24.

Sagar, A., Rathore, P., Ramteke, P. W., Ramakrishna, W., Reddy, M. S., Pecoraro, L., 2021. Plant growth promoting rhizobacteria, arbuscular mycorrhizal fungi and their synergistic interactions to counteract the negative effects of saline soil on agriculture: Key macromolecules and mechanisms. Microorganisms, 2021(9): 1-19.

Sales, C. R. G., Wang, Y., Evers, J. B., Kromdijk, J., 2021. Improving $\mathrm{C} 4$ photosynthesis to increase productivity under optimal and suboptimal conditions. J. Exp. Bot., 72(17): 5942-5960.

Sardans, J., Penuelas, J., 2021. Potassium control of plant functions: Ecological and agricultural implications, Plants, 2021(10): 419. 
Savarino, G., Corsello, A., Corsello, G., 2021. Macronutrient balance and micronutrient amounts through growth and development. Ital. J. Pediatr., 2021(47): 109.

Shang, L., Shang, L., Wan, L., Zhou, X., Li, S., Li, X., 2020. Effects of organic fertilizer on soil nutrient status, enzyme activity, and bacterial community diversity in Leymus chinensis steppe in Inner Mongolia, China. PLoS One, 15(10): e0240559.

Shrestha, J., Kandel, M., Subedi, S., Shah, K. K.. 2020. Role of nutrients in rice (Oryza sativa L.): A review. Agrica, 9(1): 53-52.

Siahpoosh, M., R., 2014. Sugar partitioning and sinksource modification in plants. Rice Res.: Open Access, 3(1): 1-3.

Song, W., Liu, S., Meng, L., Xue, R., Wang, C., Liu, G., Dong, C., Wang, S., Dong, J., Zhang, Y., 2015. Potassium deficiency inhibits lateral root development in tobacco seedlings by changing auxin distribution. Plant Soil, 396(1-2): 163-173.

Stephens, S., Mahadevan, R., Allen, D. G., 2021. Engineering photosynthetic bioprocesses for sustainable chemical production: A review. Front. Bioeng. Biotechnol., 8: 610723.

Stigter, K. A., Plaxton, W. C., 2015. Molecular mechanisms of phosphorus metabolism and transport during leaf senescence. Plants, 4: 773798.

Sugiura, Y., Akiyama, R., Tanaka, S., Yano, K., Kameoka, H., Marui, S.,Saito, M., Kawaguchi, M., Akiyama, K., Saito, K., 2020. Myristate can be used as a carbon and energy source for the asymbiotic growth of arbuscular mycorrhizal fungi. Proc. Nat. Acad. Sci. (USA), 117(41): 25779-25788.

Sustr, M., Soukup, A., Tylova, E., 2019. Potassium in root growth and development. Plants, 8: 435.

Szulc, P., Barłog, P., Deręgowska, K. A., Mejza, I., Cisowska, J. K., Ligaj, M., 2020. Effect of phosphorus application technique on effectiveness indices of its use in maize cultivation. Plant Soil Environ., 66(10): 500-505.

Torabian, S., Abriz, S. F., Qin, R., Noulas, C., Sathuvalli, V., Charlton, B., Loka, D. A., 2021.
Potassium: A vital macronutrient in potato production-a review. Agronomy, 11: 543.

Trejo, D., Conde, W. S., Pardo, M. E. G., Banuelos, J., 2021. Mycorrhizal inoculation and chemical fertilizer interactions in pineapple under field conditions. Agriculture, 11: 934.

Trivana, L., Pradhana, A. Y., 2017. Time optimization of the biocomposting and quality of organic fertilizer based on goat manure and coconut coir dust using promi and orgadec bio-activator. J. Sain Vet., 35: 136.

Vysotskaya, L., Akhiyarova, G., Feoktistova , A., Akhtyamova, Z., Korobova, A., Ivanov, I., Dodd, I., Kuluev, B., Kudoyarova, G., 2020. Effects of phosphate shortage on root growth and hormone content of barley depend on capacity of the roots to accumulate ABA. Plants, 9: 1722.

Walker, B. J. Kramer, D. M., Fisher, N., Fu, X., 2020. Flexibility in the energy balancing network of changing environmental conditions. Plants, 9: 301.

Wang, Y., Chen, Y. F., Wu, W. H., 2021. Potassium and phosphorus transport and signaling in plants. J. Integr. Plant Biol., 63(1): 34-52.

Xu, X., Du, X., Wang, F., Sha, J., Chen, Q., Tian, T., Zhu, Z., Ge, S., Jiang, Y., 2020. Effects of potassium levels on plant growth, accumulation and distribution of carbon, and nitrate metabolism in apple dwarf rootstock seedlings. Front. Plant Sci., 11: 904.

Xue, L., Wang, E., 2020. Arbuscular mycorrhizal associations and the major regulators. Front. Agric. Sci. Eng., 7(3): 296-306.

Yavari, N., Tripathi, R., Wu, B. S., Pherson, S. M., Singh, J., Lefsrud, M., 2021. The effect of light quality on plant physiology, photosynthetic, and stress response in Arabidopsis thaliana leaves. PLoS One, 16(3): e0247380.

Yu, M., Wang, Q., Tao, W., Liu, G., Liu., Wang, L., Ma, L., 2020. Interactions between arbuscular mycorrhizal fungi and soil properties jointly influence plant $\mathrm{C}, \mathrm{N}$, and $\mathrm{P}$ stoichiometry in West Lake, Hangzhou. RSC Advances, 10: 3994339953.

\section{How to cite this article:}

Akib, M. A., Antonius, S., Kuswinanti, T., Syatrawati, Dewi, T. K., Sutisna, E., 2021. Application of biocompost enriched with arbuscular mycorrhizae for the growth of Allium cepa L. Int. J. Curr. Res. Biosci. Plant Biol., 8(12): 916. doi: https://doi.org/10.20546/ijcrbp.2021.812.002 